\title{
Ameliorate salinity effect through sulphur application and its effect on some soil and plant characters under different water quantities
}

\author{
Mgdi Abdelhamid $^{1^{*}}$, Ebtisam Eldardiry ${ }^{2}$, Mohamed Abd El-Hady ${ }^{2}$ \\ ${ }^{1}$ Botany Department, National Research Centre, Cairo, Egypt; ${ }^{*}$ Corresponding Author: mansourhani2011@gmail.com \\ ${ }^{2}$ Water Relations and Field Irrigation Department, National Research Centre, Cairo, Egypt \\ Received 5 December 2012; revised 8 January 2013; accepted 16 January 2013
}

\section{ABSTRACT}

The main objective of this work is to study the effect of sulphur application and irrigation water quantity on some soil properties of the calcareous soils and to limit the suitable concentration to obtain satisfactory yield of faba beab under saline conditions. The study area (Tamyia district, Fayoum Governorate, Egypt) is characterized by a hot and dry climate in general with annual rainfall average of $8 \mathrm{~mm} /$ year, whereas the evaporation rates average ranging between 3.5 to $10 \mathrm{~mm} /$ day. Faba bean (Vicia faba L.) was sown at 18 November 2010 and harvested at 26 April 2011. Total water consumed during faba bean growing season were 623.7 and $747.2 \mathrm{~m}^{3}$ I fed for $100 \%$ and $120 \%$ irrigation treatments with increasing ranged between $3.5 \%$ and $3.7 \%$ in same sequence. Results showed that values of soil $\mathrm{EC}, \mathrm{pH}$ and $\mathrm{CaCO}_{3}$ was improved as a result of both irrigation and $S$ treatments. The improvement resulted in a gradual reduction of the studied soil properties by about $10.3 \%, 3.2 \%$; $17.0 \%$ and $23.1 \%, 4.3 \% ; 11.3 \%$ comparing $S$ treated plot relative to the control plot at 100 and $120 \%$ irrigation treatments. Application S improved water content under studied soil constant and these increases were $8.8 \%, 11.8 \%$, $8.3 \%$ and $16.9 \%$ for SP, FC, WP and AW, respectively relative to the control plots. Irrigation $100 \%$ had a positive effect on the drainable pores\% which increased by about $7.0 \%$ comparing with $120 \%$ irrigation treatments. While hydraulic conductivity increased by about $16.4 \%$ and percentage of increase drainable pores was $14.0 \%$ and $21.4 \%$ for $100 \%$ and $120 \%$ irrigation treatments comparing 3rd layer with the 1st one, respectively. Increasing irrigation water from $100 \%$ to $120 \%$ resulted increasing in the studied macronutrients, $\mathrm{N}, \mathrm{P}$ and $\mathrm{K}$, by about $80.8 \%$, $144.9 \%$ and $72.9 \%$, respectively; while they increased in plant by about $118.8 \%, 132.8 \%$ and $62.2 \%$ as compared with the control one, respectively as a result of $S$ application. Results showed that $\mathrm{Na}, \mathrm{Cl}$ and $\mathrm{Na} / \mathrm{K}$ ratio that increasing irrigation water caused increase by $2.02 \%$, $11.11 \%$ for $\mathrm{Na}$ and $\mathrm{Cl}$, while reduction in the ratio between $\mathrm{Na}$ and $\mathrm{K}$ was observed with value $-15.7 \%$ as compared 120 with $100 \%$ irrigation treatments. S application cause slightly increases in $\mathrm{Na}$ content (3.55\%) and moderately increases with $\mathrm{Cl}$ (34.38\%), which led to decrease Na:K ratio by about $39.4 \%$. Increasing irrigation water by $20 \%$ resulted in a gradual increase of both yield and water use efficiency (WUE) of faba bean plants compared with the control plants. Irrigation treatments significantly decreased the contents of proline in dry weight seed of faba bean gradually as a result of increase irrigation quantity (from $100 \%$ to $120 \%$ ) and the reduction was $9.7 \%$. While $S$ addition decreased proline by about $15.9 \%$. According to the interaction effect between irrigation and $S$ application treatments, $\mathbf{S}$ improved proline content by about $20.4 \%$ and $11.2 \%$ relative to the control treatments under $100 \%$ and $120 \%$ irrigation treatments, respectively $\%$.

Keywords: Calcareous Soil; Faba Bean; Sulphur; Soil Properties; Yield Characters; Fayoum

\section{INTRODUCTION}

The major limitation to legume production in many areas of the world is soil salinity [1], which is a longstanding problem for irrigated agriculture in arid and semiarid regions. [2] reported that in Egypt, the area of irrigated land that is salt-affected is $33 \%$. Soil degrada- 
tion led to deterioration of soil structure, nutrients loss, build-up of salts and desertification alone or in combination [3]. It was found that shoot growth is often suppressed more than the root growth by soil salinity [4]. However, fewer studies on the effect of soil salinity on root growth have been conducted [5]. The high salt content lowers osmotic potential of soil water and conesquently the availability of soil water to plants. Under extreme salinity conditions, plants may be unable to absorb water and will wilt, even when the surrounding soil is saturated. So, the salt-induced water deficit is one of the major constraints for plant growth in saline soils. In addition, many nutrient interactions in salt-stressed plants can occur that may have important consequences for growth [1]. An understanding of growth and survival of plants under saline habitat conditions is needed.

There are two major approaches to improving and sustaining productivity under saline condition: availability of fresh water to leach out excess salts in soil profile, and application of the suitable amendment, either singly or in combination [6], but the first approach has been used more extensively through acidification of irrigation water because it enables the plants to respond better not only to water but also to other production inputs such as soil physical and chemical properties.

Improvement of salt affected soil is usually initiated by the downward displacement of surface-accumulated salts [7]. [8] stated that management of salt-affected soils is a challenge, because salts affect many processes: 1) Crop growth (including yield, quality, and economic return), 2) Soil physical properties (such as aggregation and water infiltration), and 3) Sufficiency and toxicity of nutrients. They added science amelioration of salt affected soils depends on the movement of water through the soil profile to remove excess salts from the root zone, it is important that leaching and drainage for salinity control should 1) minimize flow of water through the soil profile to reduce dissolution of soil minerals and 2) reduce drainage volume.

Several products have been used as soil amendments such as $\mathrm{CaCl}_{2}, \mathrm{HSO}$ and $\mathrm{CaSO}_{4}$. For many years, elemental sulphur (S) and sulphuric acid, especially under drip irrigation systems, have been used for reclamation and improvement of saline and alkaline soils and oxidation of S is slow, so this method may be of limited value [9]. They added that $\mathrm{S}$ inoculated with Thiobacillus reduced both soil $\mathrm{EC}$ and $\mathrm{pH}$, and $\mathrm{Ca}^{2+}$ release in soil solution and consequently modified soil SAR. However, the buffering capacity of lime limits the effect of both.

On calcareous soils, S may be added to furnish calcium indirectly [10], which is oxidized to sulfuric acid, which reacts with the calcium carbonate to form gypsum $\left(\mathrm{CaSO}_{4} \cdot 2 \mathrm{H}_{2} \mathrm{O}\right)$ that consider the cheapest, soluble calcium source [11]. Water movement in soil was improved under acidification treatment except under increase salinity water and sulphoric acid $(0.05 \%)$. Acidification of the water can result in immediate changes, though often of short duration, in the soil water $\mathrm{pH}$.

Beans are reported to be sensitive to salt but some species may be moderately tolerant [12]. [13] mentioned that with cropping throughout the year, if the water requirement of crops were satisfied and drainage was accomplished properly, the risk of soil salinization could be avoided. Also, successful salt management requires frequent monitoring not only soil but also irrigation water. Salt stress, like many abiotic stresses factors, adversely affects plant growth and productivity. Plants exposed to salt stress adapt their metabolism in order to cope with the changed environment. Survival under these stressful conditions depends on the plant's ability to perceive the stimulus, generate and transmit signals and instigate biochemical changes that adjust metabolism accordingly [14].

The main objective of this work is to study the effect of sulphur application and irrigation water on some soil properties of the calcareous soils and to limit the suitable concentration to obtain satisfactory yield of faba beab under saline conditions.

\section{MATERIAL AND METHODS}

\subsection{Site Description}

Field trail was conducted at Tamyia district, Fayoum Governorate, Egypt, 29.77N, 31.30E (Figure 1). The study area is characterized by a hot and dry climate in general with scanty rainfall drops that may occurs between December-April with annual average of $8 \mathrm{~mm} /$ year, whereas the evaporation rates average ranging between 3.5 to $10 \mathrm{~mm} / \mathrm{day}$; the minimum and maximum air temperature values usually recorded in January and July, respectively [15].

\subsection{Soil Preparation and Planting}

Field trail was conducted to study the effect of elemental sulphur (S) application and different irrigation quantity on faba bean grown under saline soil conditions calcareous in nature. Canal irrigation water was used after acidified by $0.05 \%$ sulphoric acid to decrease soil $\mathrm{pH}$ and accelerate transformation elemental sulphur to the sulphate. Drip irrigation was used $75 \mathrm{~cm}$ between laterals (JR $30 \mathrm{~cm}$ among dripper, 4 liter $/ \mathrm{h}$ ). Farmyard manure, ammonium sulphate $(20.5 \% \mathrm{~N})$, single superphosphate $\left(15.5 \% \mathrm{P}_{2} \mathrm{O}_{5}\right)$ and potassium sulphate $\left(50 \% \mathrm{~K}_{2} \mathrm{O}\right)$ at rate of $20 \mathrm{~m}^{3}, 100,150$ and $50 \mathrm{~kg} / \mathrm{fed}$, respectively were spread in the soil surface before soil preparation and mixed well with the upper layer $(30 \mathrm{~cm})$. Faba bean (Vicia faba L. cv. Giza 40) seeds were selected for uniformity. Seedlings were thinned to three seedlings per 


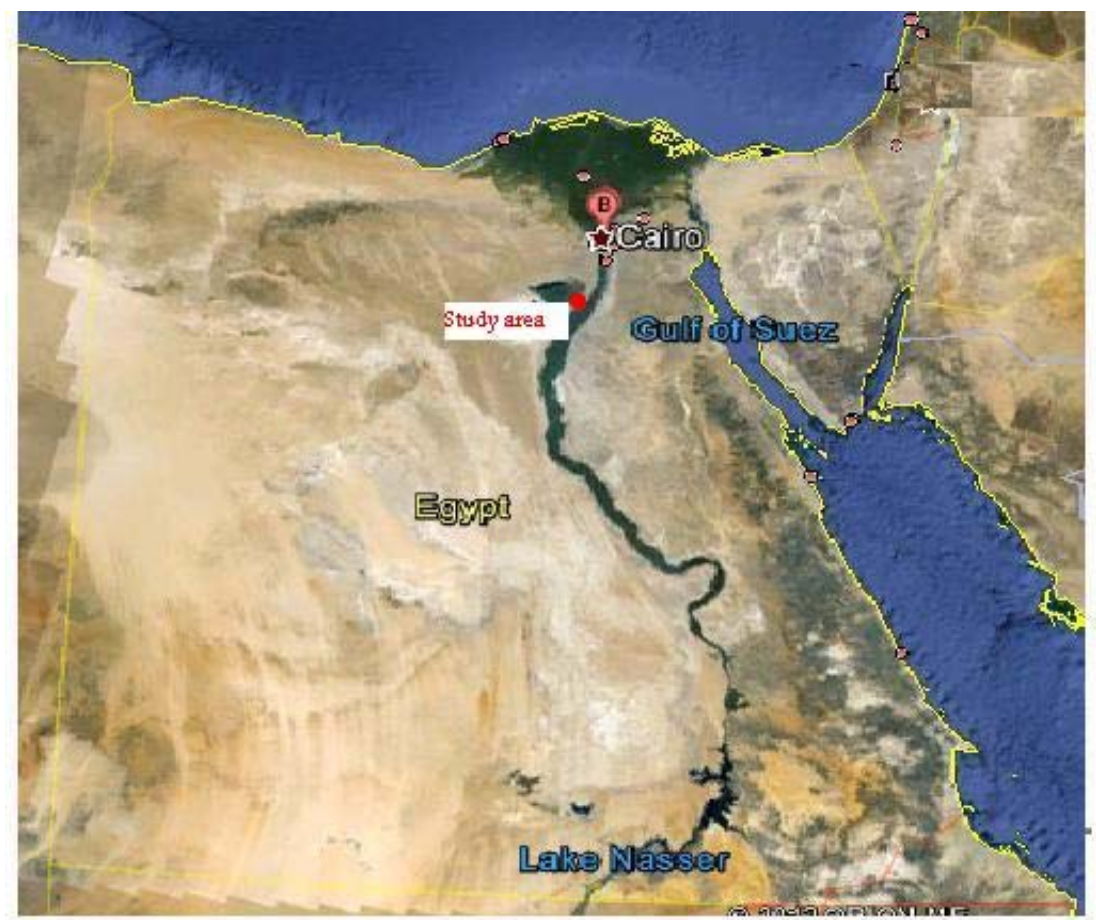

Figure 1. Experimental site location.

hole 10 days after planting. Faba bean plants lasted 160 days. The experiment was a factorial arrangement with two levels of irrigation water (100\% and $120 \%$ from ETo) and two induced sulfur levels 0 (Control) and $200 \mathrm{~kg} / \mathrm{fed}$ with three replicates.

\subsection{Irrigation Process and Quantity}

Irrigation water was added as a ratio from ETo (Fayoum Meteo Station ) at $100 \%$ and $120 \%$. No. of irrigations water were 6 (during Nov, Dec 2010 and Jan 2011), 8 (Feb), 12 (Mar) and 1 (April), 2011 with monthly amounts ranged between 23.5 to 241.9 and 28.2; 290 $\mathrm{m}^{3} /$ fed for April and March with total calculated 601.4 and $721.7 \mathrm{~m}^{3} /$ fed for $100 \%$ and $120 \%$ irrigation treatments, respectively. The total water consumptive during faba bean growing season was 623.7 and $747.2 \mathrm{~m}^{3} / \mathrm{fed}$ with increasing ranged between $3.5 \%$ and $3.7 \%$, respectively.

\subsection{Soil Analysis}

Some soil characteristics of the investigated soil used in the experiment before cultivation are determined after [16] i.e. $\mathrm{CaCO}_{3}(14.21 \%), \mathrm{OM}(0.46 \%)$, ECe $(7.75$ $\mathrm{dSm}^{-1}$ in soil paste extract), $\mathrm{pH}$ (8.32 in soil:water 1:2.5), soulble cations were $\mathrm{Ca}^{2+} 9.32, \mathrm{Mg}^{2+} 4.20, \mathrm{Na}^{+} 62.74$ and $\mathrm{K}^{+} 1.20 \mathrm{meq} / \mathrm{liter}$ while soluble anions were $\mathrm{HCO}_{3}^{-} 4.12$, $\mathrm{Cl}^{-}$52.26, $\mathrm{SO}_{4}=21.09 \mathrm{meq} /$ liter in extracted soil paste. Soil is loamy sand in texture.

Hydraulic conductivity (HC) was measured in the la- boratory under a constant head technique [17] using the following formula: $\mathrm{HC}=(\mathrm{QL}) /(\mathrm{At} \Delta \mathrm{H})$, where: $\mathrm{HC}$ : water quantity flowing through saturated soil sample/area/ unit time, Q: volume of water flowing through saturated soil sample per unite time $\left(\mathrm{L}^{3} / \mathrm{t}\right)$, A: cross sectional flow area $\left(\mathrm{L}^{2}\right) \mathrm{L}$ : length of the soil sample and $\Delta \mathrm{H}$ : differences in hydraulic head across the sample (L) and t: time (hr).

Soil water retention at 0.1 (FC) and 15.0 (WP) bars were estimated after [18]. Soil available water was calculated by subtracting FC - WP.

\subsection{Plant Analysis}

Plant samples were taken at harvest for measurement of dry weight of shoot, total-N, proline, and some mineral contents of shoots. Seed yield and some chemical constituents of the yielded seeds were also determined at harvest.

Total-N and mineral contents of N. P, K and Na were determined after [16]. Proline was estimated according to [19].

\subsection{Statistical Analysis}

The data were subjected to the analysis of variance (ANOVA) appropriate to the split plot in a randomized complete block design applied after testing the homogeneity of error variances according to the procedure outlined by [20]. The significant differences (LSD) between treatments were compared with the critical difference at $5 \%$ probability level. 


\section{RESULTS AND DISCUSSION}

Table 1 illustrated the effect of both irrigation treatments and sulphur application on the soil $\mathrm{EC}, \mathrm{pH}$, and $\mathrm{CaCO}_{3}$ in different soil depth at the end of the faba bean growth period. Data on hand noticed that maximum values of the determined previous characteristics were observed in the surface layer $(0-5 \mathrm{~cm})$ in the case of the EC and soil $\mathrm{pH}$, 2nd layer $(5-10 \mathrm{~cm})$ in $\mathrm{CaCO}_{3}$, except under irrigation with $120 \%$ from ETo with S application.

According to the interaction effect among irrigation treatments and soil depth on the $\mathrm{EC}, \mathrm{pH}$ and $\mathrm{CaCO}_{3}$, there were gradually increase in the studied soil properties in the surface and decreased with depth in both irrigation treatments (Figure 1).

Salts in the root zone can reduce crop yield by making it difficult for roots to extract water from the soil. Salts increase soil osmotic potential, causing water to move from areas of lower salt concentration (plant tissue) into the soil where the salt concentration is higher, which can cause plants to wilt even when soil moisture is adequate. [21] stated that to assess the ecological effect (status) of salt affected soil, salts on the irrigated soil, it is necessary to determine the change of the main soil characters which are affected directly from accumulated salts such as soil EC and $\mathrm{He}$ found that $\mathrm{S}$ application in soil increases anion and cation solubilization, which led directly to increase soil $\mathrm{EC}$, as well as a higher $\mathrm{pH}$ in the soil without $\mathrm{S}$ application.

The increase in the amount of the irrigation water to the soil cultivated by faba bean resulted a gradual decrease in $\mathrm{EC}, \mathrm{pH}$ and $\mathrm{CaCO}_{3}$ content at the end of the growing season by about $0.66 \%,-1.87 \%$ and $-5.04 \%$ (Figure 1).

With respect to the effect of the irrigation treatment, both soil EC and $\mathrm{pH}$ values decreased with depth under both 100 and $120 \%$ irrigation treatments. Regardless S application the change in the studied soil characteristics for different soil depth under irrigation treatment $120 \%$ comparing with $100 \%$ were $-7.3 \%,-3.9 \%,-0.6 \%$; $-2.6 \%,-2.5 \%, 0.6 \% ;-4.1 \%,-5.7 \%,-5.3 \%$ and $57.0 \%$, $18.0 \% ;-1.4 \%$ for soil $\mathrm{EC}, \mathrm{pH}$ and $\mathrm{CaCO}_{3}$, respectively (Table 2). Same trend was obtained when comparing depth change values for control plots with sulphur treated ones.

The most important promotive effect for soil EC and $\mathrm{pH}$ was observed at the depth $(10-15 \mathrm{~cm})$ than the $1 \mathrm{st}$ one $(0-5 \mathrm{~cm})$ with values $20.0 \%, 25.9 \%, 19.2 \% ; 12 \%$ and $3.4 \%, 5.0,1.8$ and 12.7 , respectively. Regarding to the $\mathrm{CaCO}_{3}$ content, the change in the values happened in the 3rd layer $(10-15 \mathrm{~cm})$ comparing to the $1 \mathrm{st}$ one was slightly and the values were $2.4 \%, 0.0 \%, 4.7 \%, 0.0 \%$ in same sequences.

Also, values of soil EC, $\mathrm{pH}$ and $\mathrm{CaCO}_{3}$ was improved as a result of both irrigation and $\mathrm{S}$ treatments. The improvement resulted in a gradual reduction of the studied soil properties by about $10.3 \%, 3.2 \% ; 17.0 \%$ and $23.1 \%$, $4.3 \% ; 11.3 \%$ comparing $\mathrm{S}$ treated plot relative to the control plot at $100 \%$ and $120 \%$ irrigation treatments. These finding nay be attributed to the variations were not very significant. In treatments with $\mathrm{S}$, it is very probable that there was increased microbial activity which also resulted in increased $\mathrm{CO}_{2}$ level in the leach, resulting in a

Table 1. Effect of the irrigation and elemental sulphur treatments on some soil characteristics after faba bean crop.

\begin{tabular}{|c|c|c|c|c|c|c|c|}
\hline Treatments & Irrigation & & $100 \%$ & & & $120 \%$ & \\
\hline Sulphur & Depth $\mathrm{cm}$ & $\mathrm{EC}$ & $\mathrm{pH}$ & $\mathrm{CaCO}_{3}$ & $\mathrm{EC}$ & $\mathrm{pH}$ & $\mathrm{CaCO}_{3}$ \\
\hline \multirow[t]{4}{*}{ Control } & 5 & 7.75 & 8.28 & 13.98 & 7.80 & 8.12 & 13.05 \\
\hline & 10 & 7.10 & 8.21 & 14.05 & 7.10 & 8.07 & 12.81 \\
\hline & 15 & 6.20 & 8.00 & 13.65 & 6.30 & 7.97 & 12.44 \\
\hline & Mean & 7.02 & 8.16 & 13.89 & 7.07 & 8.05 & 12.77 \\
\hline \multirow[t]{5}{*}{ Sulphur } & 5 & 7.32 & 8.08 & 11.28 & 6.17 & 7.82 & 11.16 \\
\hline & 10 & 6.15 & 7.94 & 12.04 & 5.64 & 7.68 & 11.78 \\
\hline & 15 & 5.42 & 7.68 & 11.28 & 4.52 & 7.61 & 11.17 \\
\hline & & 6.30 & 7.90 & 11.53 & 5.44 & 7.70 & 11.37 \\
\hline & Mean & 6.66 & 8.03 & 12.71 & 6.26 & 7.88 & 12.07 \\
\hline \multirow[t]{3}{*}{ LSD $5 \%$} & Irrigation & 1.11 & 0.02 & 0.12 & 0.14 & 0.09 & 0.09 \\
\hline & Sulphur & 0.29 & 0.42 & 0.21 & 0.45 & 0.17 & 0.21 \\
\hline & IxS & 0.57 & ns & 0.37 & 0.69 & 0.31 & 0.42 \\
\hline
\end{tabular}


Table 2. Effect of the irrigation and elemental sulphuer treatments on some soil water constants after faba bean crop.

\begin{tabular}{|c|c|c|c|c|c|c|c|c|}
\hline \multicolumn{2}{|c|}{ Treatments } & \multirow{2}{*}{ Depth $(\mathrm{cm})$} & \multirow[t]{2}{*}{ SP } & \multirow[t]{2}{*}{$\mathrm{FC}$} & \multirow{2}{*}{$\frac{\text { WP }}{\%}$} & \multirow[t]{2}{*}{ AW } & \multirow[t]{2}{*}{ DP } & \multirow{2}{*}{$\begin{array}{c}\mathrm{HC} \\
\mathrm{cm} / \mathrm{h}\end{array}$} \\
\hline Irrigation & Sulphur & & & & & & & \\
\hline \multirow[t]{9}{*}{$100 \%$} & Control & 5 & 23.9 & 19.1 & 11.8 & 7.3 & 4.8 & 4.75 \\
\hline & & 10 & 24.8 & 20.3 & 11.9 & 8.4 & 4.5 & 5.30 \\
\hline & & 15 & 25.6 & 20.7 & 12.6 & 8.1 & 4.9 & 5.85 \\
\hline & & Mean & 24.8 & 20.1 & 12.1 & 7.9 & 4.7 & 5.30 \\
\hline & Sulphur & 5 & 25.2 & 20.2 & 12.1 & 8.1 & 5.0 & 5.34 \\
\hline & & 10 & 26.8 & 22.0 & 13.2 & 8.8 & 4.8 & 6.89 \\
\hline & & 15 & 27.3 & 22.1 & 14.4 & 7.7 & 5.2 & 7.87 \\
\hline & & Mean & 26.4 & 21.4 & 13.2 & 8.2 & 5.0 & 6.70 \\
\hline & & Mean & 25.6 & 20.7 & 12.7 & 8.1 & 4.9 & 6.0 \\
\hline \multirow[t]{12}{*}{$120 \%$} & Control & 5 & 24.6 & 20.0 & 11.7 & 8.3 & 4.6 & 5.64 \\
\hline & & 10 & 25.6 & 21.0 & 12.0 & 9.0 & 4.6 & 7.25 \\
\hline & & 15 & 27.1 & 21.7 & 12.4 & 9.3 & 5.4 & 7.82 \\
\hline & & Mean & 25.8 & 20.9 & 12.0 & 8.8 & 4.9 & 6.90 \\
\hline & Sulphur & 5 & 26.4 & 22.7 & 12.5 & 10.2 & 3.7 & 6.21 \\
\hline & & 10 & 28.1 & 23.9 & 12.9 & 11.0 & 4.2 & 7.35 \\
\hline & & 15 & 31.2 & 26.5 & 13.4 & 13.1 & 4.7 & 7.65 \\
\hline & & Mean & 28.6 & 24.4 & 12.9 & 11.4 & 4.2 & 7.07 \\
\hline & & Mean & 27.2 & 22.6 & 12.5 & 10.1 & 4.5 & 7.0 \\
\hline & LSD $5 \%$ & Irrigation & 1.2 & 0.6 & 0.3 & 3.1 & 0.2 & 0.22 \\
\hline & & Sulphur & 2.0 & 1.2 & 0.8 & 0.8 & 0.5 & 0.63 \\
\hline & & IxS & 3.2 & 2.1 & 1.6 & 1.7 & 0.7 & 1.05 \\
\hline
\end{tabular}

SP: saturation \%, FC: field capacity, WP: wilting point, AW: available water, DP: drainable pores \%, HC: hudraulic conductivity.

lower $\mathrm{pH}$ than in the untreated one, due to the lack of readily available energy source for the microbes and unfavourably high $\mathrm{pH}$ values as proposed by [22]. On the other hand, dissolved calcium, as a result to transforms some of $\mathrm{CaCO}_{3}$ to $\mathrm{CaSO}_{4}$ and increase $\mathrm{Ca}^{2+}$ in the soil phase probably replaced the sodium in the colloidal complex, this is supposed because the treatments with sulphur probably induced higher Na leaching.

Data in Table 2 showed a clearly response of soil water constant, i.e., saturation percent (SP), field capacity (FC), and wilting point (WP) in different soil depths to the both irrigation and $\mathrm{S}$ applied treatments. According to the irrigation treatments effect, data noticed that increasing irrigation quantity by $20 \%$ (from $100 \%$ to $120 \%$ from ETo) increased water content all the studied soil water constants by about 6.3, 8.6, 24.7 for SP, FC and AW, respectively. While water content at WP slightly reduced by $-1.6 \%$.
Regarding to the effect of S application, it is clearly obvious that $\mathrm{S}$ application improved water content under studied soil constant and these increase were 8.8, 11.8, 8.3 and $16.9 \%$ for SP, FC, WP and $\mathrm{AW}$, respectively relative to the control plots. From these results, both increasing irrigation water (more than crop water requirement) and application $\mathrm{S}$ led to pronounced effect of excess water content in different soil layers, especially the upper ones $(0-15 \mathrm{~cm})$, and then provide the plant by its needed.

Also, results revealed that there was significant increase in water content for the studied soil depths at most studied soil water constant where comparing soil depth $10-15 \mathrm{~cm}$ with surface layer $(0-5 \mathrm{~cm})$ and the increase percentage were 7.7, 9.1, 13.1; 2.8 and 14.3, 12.9, 6.6; $21.4 \%$ for SP, FC, WP and AW, respectively (Table 2). With respect to the soil water constants of three studied soil depths as affected by $\mathrm{S}$ application, data mentioned 
that there were increases in all studied constants i.e. SP, FC, WP and AW by about 8.7, 8.5, 6.6; 11.4 and 13.4, $13.5,13.0 ; 14.1$ for $\mathrm{S}$ untreated and treated plots when comparing $3 \mathrm{rd}$ depth with the 1 st one, respectively (Table 2).

The interaction effect of irrigation and $\mathrm{S}$ treatment on the drainable pores\% (DP) and saturated hydraulic conductivity (HC) were shown in Table 2. Results indicated that the highest values were obtained at $100 \%$ irrigation treatment, untreated $\mathrm{S}$; depth $10-15 \mathrm{~cm} \mathrm{(5.4 \% )} \mathrm{and}$ $120 \%$ irrigation treatment, treated $\mathrm{S}$; depth $10-15 \mathrm{~cm}$ $\left(8.65 \mathrm{~cm} \cdot \mathrm{h}^{-1}\right)$. While the lowest values of the drainable pores (DP) and HC were attained in 100\% irrigation treatment, untreated $\mathrm{S}$; depth $0-5 \mathrm{~cm}(3.7 \%)$ and $120 \%$ irrigation treatment, treated S; depth $10-15 \mathrm{~cm}(4.75 \%)$, respectively.

Regarding to irrigation treatment, and regardless to the soil depth data noticed that irrigation $100 \%$ had a positive effect on the DP\% which increased by about $7.0 \%$ comparing with $120 \%$. While HC increased by about $16.4 \%$ and percentage of increase DP was $14.0 \%$ and $21.4 \%$ for $100 \%$ and $120 \%$ irrigation treatments comparing 3rd layer with the 1 st one, respectively. But the improvement in the 3 rd layer relative to the 1 st one was better in $100 \%$ than $120 \%$ with values $36.0 \%$ and $30.5 \%$, respectively in case of $\mathrm{HC}$ values.

The opposite was true after S application and the increment values were $31.6 \%$ and $34.4 \%$ for control and treated treatments. The maximum $\mathrm{HC}$ value $(7.87 \mathrm{~cm} / \mathrm{h})$ resulted in 3rd soil layer treated with $\mathrm{S}$, while the minimum one $(4.75 \mathrm{~cm} / \mathrm{h})$ was obtained in the 1 st soil layer as affected by irrigation treatment $100 \%$ and the change between them was $60.5 \%$. This finding agreed with those obtained by $[3,23]$, who stated that sulfuric acid injected in irrigation water increases the electrical conductivity of the soil solution, which helps in increase electrolyte concentrations that increase the rate of water penetration through decrease clay swelling under sodic conditions. Also, $[11,24]$ reported that permeability is thereby improved by increased clay flocculation coupled with decreased clay swelling. Because the solubility of gypsum is relatively low, more time and water are required for it to react well. As a single amendment, sulfuric acid is thought to be superior to gypsum. However, with increased hydraulic conductivity, potential amendment losses preclude the effectiveness of sulfuric acid.

Changing in the $\mathrm{HC}$ may be attributed to one or more of the following: 1) surface layer exposed to the weather condition and hence dry/wet cycles was carried out, which affect directly on the soil aggregate formation [25], 2) sulphur was well mixed in the upper layer than the deep ones, 3) increased water content in the deep layer did not allow to form aggregation well, that help in increasing redox potential, and 4) release $\mathrm{Ca}^{2+}$ in soil solution plays an important role in adjust soil SAR and encourage formation of soil aggregates. [26] found that surface applications of gypsum, sulfuric acid and [gypsum and $\mathrm{Ca}\left(\mathrm{NO}_{3}\right)_{2}$ ] were equally effective in improving infiltration rates compared to the control within one year of application. They added that most surface applied amendments improved crop yields in three of four years.

Table 3 illustrated some recorded (studied plant characters such as plant height, No. of branches/plant, No. of pods/plant, seeds weight/plant, seed yield and seed index. Data noticed that the highest values of the studied plant characters were observed under irrigation treatment $120 \%$ and under sulphur application. According to the effect of irrigation treatment, one can notice that irrigation treatment $120 \%$ was better than $100 \%$ under all studied characters. The increase of the characters value in was $12.7 \%, 21.3 \%, 55.8 \%, 12.9 \%, 3.5 \%$ and $5.4 \%$ comparing $120 \%$ to $100 \%$ irrigation treatments in same sequence. Regardless, irrigation treatments effect, sulphur application has a promotive effect on the studied

Table 3. Effect of irrigation treatment and sulfur application on the plant characters of faba bean plants.

\begin{tabular}{|c|c|c|c|c|c|c|c|c|}
\hline \multirow{2}{*}{ Irrigation } & \multirow{2}{*}{ Sulfur } & \multirow{2}{*}{$\begin{array}{c}\text { Plant } \\
\text { height }(\mathrm{cm})\end{array}$} & Branches & Pods & Seeds & \multirow{2}{*}{$\begin{array}{c}\text { Seed index } \\
\text { w/100 seeds }\end{array}$} & \multirow{2}{*}{$\begin{array}{l}\text { Seed yield } \\
\text { plant }\end{array}$} & \multirow{2}{*}{$\begin{array}{c}\text { Yield } \\
\text { tone/fed }\end{array}$} \\
\hline & & & & Plant & & & & \\
\hline \multirow[t]{3}{*}{$100 \%$} & Control & 87.0 & 3.3 & 3.7 & 19.7 & 118.1 & 37.2 & 1.562 \\
\hline & Sulfur & 109.4 & 4.3 & 5.0 & 22.3 & 121.3 & 43.9 & 1.842 \\
\hline & Mean & 98.2 & 3.8 & 4.3 & 21.0 & 119.7 & 40.5 & 1.702 \\
\hline \multirow[t]{3}{*}{$120 \%$} & Control & 107.6 & 4.7 & 6.7 & 21.4 & 120.4 & 39.4 & 1.653 \\
\hline & Sulfur & 113.8 & 6.7 & 6.7 & 26.0 & 127.4 & 46.0 & 1.931 \\
\hline & Mean & 110.7 & 5.7 & 6.7 & 23.7 & 123.9 & 42.7 & 1.792 \\
\hline \multirow[t]{3}{*}{ LSD 5\% } & Irrigation & 1.6 & 0.2 & 0.3 & 0.4 & 1.8 & 1.3 & 0.023 \\
\hline & Sulphur & 3.2 & 0.5 & 0.9 & 1.1 & 3.1 & 3.2 & 0.071 \\
\hline & IxS & 5.1 & 0.9 & 1.6 & 1.8 & 4.2 & 5.2 & 0.142 \\
\hline
\end{tabular}


plant characters. The increments of the studied characters value were $14.7 \%, 25.0 \%, 11.5 \%, 17.5 \%, 3.4 \%$, and $17.2 \%$ as compared with the control (sulphur untreated plot) in same sequences. Relative to the interaction effect between irrigation and $\mathrm{S}$ application treatments, most of the highest values were obtained in sulphur treated plots under irrigation treatment 100 followed by 120\% (Table 3).

Also, data noticed that increased irrigation by $20 \%$ increased yield by about $5.8 \%$ under control treatment, while the increase percentage was 4.9 comparing $\mathrm{S}$ treated plot under $120 \%$ with $100 \%$ irrigation treatments. Regardless S effect, yield increased by about $5.3 \%$ as a result of increase irrigation water by $20 \%$. Whereas, treated soil by $\mathrm{S}$ increased yield by about $16.8 \%$ and $17.9 \%$ under $100 \%$ and $120 \%$ irrigation treatments. These results explained on the base of accumulation of excessive salt in irrigated soils (by 100\%) expressed in soil EC can reduce crop yields, reduce the effectiveness of irrigation, ruin soil structure, and affect other soil properties [27].

Table 4 showed plant fresh and dry weight, and N, P, $\mathrm{K}, \mathrm{Na}$ and $\mathrm{Cl}$. According to the irrigation treatment, data mentioned that $120 \%$ irrigation treatment was better that $100 \%$ and had the highest values of the previous faba bean plant characters. Plant fresh and dry weight of faba bean was improved and increased by about $8.6 \%$ and $21.3 \%$ when increase irrigation water by $20 \%$, respectively. Regarding to the $\mathrm{S}$ effect, application $\mathrm{S}$ developed faba bean fresh and dry weight by about $5.2 \%$ and $2.3 \%$ relative to the control treatment.

Data in Table 3 showed that, increasing irrigation water by $20 \%$ from $100 \%$ to $120 \%$ resulted in a gradual increase of both yield and water use efficiency (WUE) of faba bean plants compared with the control plants. Irri- gation water resulted in increasing yield by $5.3 \%$ comparing $120 \%$ with $100 \%$ and $17.3 \%$ comparing $S$ treated plot with untreated one.

While WUE values were $-12.1 \%$ and $17.0 \%$ in same sequences. The inhibitory effect of salt stress on yield was also reported by other investigators using various plant species $[28,29]$. The decrease WUE at $100 \%$ irrigation treatment due to increasing salinity levels and could be ascribed to the increase salts in soil and hence increase osmotic pressure. Also, the improvement in yield relative to $120 \%$ irrigation treatments was not matched to the amount of water used in $100 \%$ one.

With respect to the $\mathrm{N}, \mathrm{P}$ and $\mathrm{K}$ content, data revealed that increase irrigation water from $100 \%$ to $120 \%$ from ETo resulted increasing in the studied macronutrients $(\mathrm{N}$, $\mathrm{P}$ and $\mathrm{K}$ ) by about $80.8 \%, 144.9 \%$ and $72.9 \%$, respecttively.

According to the effect of S application on N, P and K content, results noticed that they increased in plant by about $118.8 \%, 132.8 \%$ and $62.2 \%$ as compared with the control one, respectively. This decrease in total $\mathrm{N}$ was also observed by [30,31]. This decrease in total $\mathrm{N}$ content may be attributed to water disruption of the machinery consequent to water deprivation.

Regarding to the $\mathrm{Na}, \mathrm{Cl}$ and $\mathrm{Na} / \mathrm{K}$ ratio, results showed that increasing irrigation water caused increase percentage by $2.02 \%, 11.11 \%$ for $\mathrm{Na}$ and $\mathrm{Cl}$ while reduction in the ratio between $\mathrm{Na}$ and $\mathrm{K}$ was observed with value $-15.7 \%$ as compared $120 \%$ with $100 \%$. Regardless irrigation treatment $\mathrm{S}$ application cause slightly increases in $\mathrm{Na}$ content (3.55\%) and moderately increases with $\mathrm{Cl}$ (34.38\%), which led to decrease $\mathrm{Na}$ : K ratio by about 39.4 .

Irrigation treatments significantly decreased the contents of proline in dry weight seed of faba bean gradually (Table 3) as a result of increase irrigation quantity (from

Table 4. Effect of irrigation treatment and sulfur application on the nutrient content in faba bean plants.

\begin{tabular}{|c|c|c|c|c|c|c|c|c|c|c|}
\hline \multicolumn{2}{|c|}{ Treatments } & \multicolumn{2}{|c|}{ Plant weigh (g) } & \multirow[t]{2}{*}{$\mathrm{N}$} & \multirow[t]{2}{*}{$\mathrm{P}$} & \multirow[t]{2}{*}{$\mathrm{K}$} & \multirow[t]{2}{*}{$\mathrm{Na} \%$} & \multirow[t]{2}{*}{$\mathrm{Cl} \%$} & \multirow[t]{2}{*}{$\mathrm{Na} / \mathrm{K}$} & \multirow{2}{*}{$\begin{array}{l}\text { Free proline } \\
\left(\mathrm{mg} \cdot \mathrm{g}^{-1} \mathrm{DW}\right)\end{array}$} \\
\hline Irrigation & Sulfur & Fresh & Dry & & & & & & & \\
\hline \multirow[t]{3}{*}{$100 \%$} & Control & 195.6 & 63.8 & 1.61 & 0.290 & 1.45 & 1.96 & 0.08 & 1.4 & 0.98 \\
\hline & Sulfur & 219.2 & 76.0 & 1.78 & 0.623 & 2.29 & 3.36 & 0.24 & 1.5 & 1.09 \\
\hline & Mean & 207.4 & 69.9 & 1.70 & 0.457 & 1.87 & 2.66 & 0.16 & 1.4 & 1.04 \\
\hline \multirow[t]{3}{*}{$120 \%$} & Control & 212.3 & 64.0 & 2.25 & 0.591 & 1.64 & 3.15 & 0.29 & 1.9 & 1.03 \\
\hline & Sulfur & 223.8 & 79.1 & 5.20 & 1.538 & 3.08 & 5.09 & 0.50 & 3.3 & 1.24 \\
\hline & Mean & 218.1 & 71.5 & 3.72 & 1.064 & 2.36 & 4.12 & 0.40 & 2.6 & 1.14 \\
\hline \multirow[t]{3}{*}{ LSD $5 \%$} & I & 1.0 & 1.3 & 0.5 & 0.290 & 0.18 & 0.16 & 0.18 & 0.1 & 0.03 \\
\hline & $\mathrm{S}$ & 2.3 & 3.2 & 1.3 & 0.571 & 0.31 & 0.43 & 0.22 & 0.2 & 0.09 \\
\hline & $\mathrm{I} \times \mathrm{S}$ & 6.11 & 8.79 & 1.7 & 0.883 & 0.56 & 0.78 & 0.34 & 0.2 & 0.13 \\
\hline
\end{tabular}


$100 \%$ to $120 \%$ ) and the decrease percentage was $9.7 \%$. While $\mathrm{S}$ addition decreased proline by about $15.9 \%$. According to the interaction effect between irrigation and $\mathrm{S}$ application treatments, $\mathrm{S}$ improved proline content by about $20.4 \%$ and $11.2 \%$ relative to the control treatments under $100 \%$ and $120 \%$ irrigation treatments, respectively $\%$. This result supported by [32] who found that increasing soil salinity lead to increase in sodium content in tomato plants. Also, the inhibitory effect of salt stress on shoot dry weight was also reported by other investigators using various plant species [31]

\section{ACKNOWLEDGEMENTS}

This work was a part of Research Project 9050105 supported by the National Research Centre, Cairo, Egypt.

\section{REFERENCES}

[1] Manchanda, G. and Garg, N. (2008) Salinity and its effects on the functional biology of legumes. Acta Physiologica Plant, 30, 595-618. doi:10.1007/s11738-008-0173-3

[2] Ghassemi, F., Jakeman, A.J. and Nix, H.A. (1995) Salinization of land and water resources: Human causes, extent, management and case studies. UNSW Press, Sydney, CAB International, Wallingford.

[3] Mace, J.E. and Amrhein, C. (2001) Leaching and reclamation of a soil irrigated with moderate SAR waters. Soil Science Society of America Journal, 65, 199-204. doi:10.2136/sssaj2001.651199x

[4] Ramoliya, P.J., Patel, H.M. and Pandey, A.N. (2006) Effect of salinization of soil on growth and nutrient accumulation in seedlings of Prosopis cineraria. Journal of Plant Nutrition, 29, 283-303. doi:10.1080/01904160500476806

[5] Munns, R. (2002) Comparative physiology of salt and water stress. Plant Cell and Environment, 25, 239-250. doi:10.1046/j.0016-8025.2001.00808.x

[6] Tyagi, N.K. and Sharma, D.P. (2000) Disposal of drainage water: Recycling and reuse. Proceedings 8 ICID International Drainage Workshop, New Delhi, 31 January4 February 2000, 199-213.

[7] Gilfedder, M., Mein, R.G. and Connel, L.D. (2000) Border irrigation field experiment. II: Salt transport. Journal of Irrigation and Drainage Engineering, 126, 92-97. doi:10.1061/(ASCE)0733-9437(2000)126:2(92)

[8] Qadir, R., Ghafoor, A. and Murtaza, G. (2000) Amelioration strategies for saline soils: A review. Land Degradation and Development, 11, 501-521. doi:10.1002/1099-145X(200011/12)11:6<501::AID-LDR 405>3.0.CO;2-S

[9] Hilal, M.H. and Abd-Elfattah, A. (1987) Effect of $\mathrm{CaCO}_{3}$ and clay content of alkaline soils in their response to added sulphur. Sulfur in Agriculture, 11, 15-19.

[10] Balbaa, A.M. (1995) Management of problem soils in arid ecosystems. CRC/Lewis Publishers, Boca Raton.
[11] Abd El-Hady, M. and Shaaban, S.M. (2010) Acidification of saline irrigation water as a water conservation technique and its effect on some soil properties. AmericanEurasian Journal of Agricultural \& Environmental Sciences, 7, 463-470.

[12] Zahran, H.H. (1991) Conditions for successful Rhizobium legume symbiosis in saline environments. Biology and Fertility of Soils, 12, 73-80. doi:10.1007/BF00369391

[13] Hussain, M.A. and Sadiq, M. (1982) Effect of fallowing and cropping on soil salinization. Engineering News, 24, 122.

[14] Hasegawa, P.M., Bressan, R.A., Zhu, J.K. and Bohnert, H.J. (2000) Plant cellular and molecular responses to high salinity. Annual Review of Plant Physiology and Plant Molecular Biology, 51, 463-499. doi:10.1146/annurev.arplant.51.1.463

[15] Shendi, M.M., Abdelfattah, M.A. and Harbi, A. (2010) Spatial monitoring of soil salinity and prospective conservation study for Sinnuris district soils, Fayoum, Egypt. ICSC International Conference on Soil Classification and Reclamation of Degraded Lands in Arid Environments, Abu Dhabi, 17-19 May 2010.

[16] Rebecca, B. (2004) Soil survey methods manual. Soil Survey Investigations Report. No 42, Natural Resources Conservation Services.

[17] Klute, A. and Dirksen, C. (1986) Hydraulic conductivity and diffusivity. Laboratory methods. In: Klute, A., Ed., Methods of Soil Analysis, Part 1. Physical and Mineralogical Methods. ASA and SSSA, Madison, 687-734.

[18] Klute, A. (1986) Water retension. Laboratory methods. In: Klute, A., Ed., Methods of Soil Analysis, Part 1. Physical and Mineralogical Methods. ASA and SSSA, Madison, 635-662.

[19] Bates, L.S., Waldan, R.P. and Teare, L.D. (1973) Rapid determination of free proline under water stress studies. Plant and Soil, 39, 205-207. doi:10.1007/BF00018060

[20] Dospekhov, B.A. (1984) Field experimentation. Statistical procedures. Mir Publishers, Moscow.

[21] Aguirre, J.G.L., Larios, J.F. and Ochoa, J.M. (2007) Salt leaching process in an alkaline soil treated with elemental sulphur under dry tropic conditions. World Journal of Agricultural Sciences, 3, 356-362.

[22] Kosmas, C. and Moustakas, N. (1990) Hydraulic conductivity and leaching of an organic saline-sodic sodic soil. Soil Science Society of America Journal, 53, 1531-1536.

[23] Mace, J.E., Amrhein, C. and Oster, J.D. (1999) Comparison of gypsum and sulfuric acid for sodic soil reclamation. Arid Soil Research and Rehabilitation, 13, 171-188. doi:10.1080/089030699263401

[24] Tayel, M.Y. and Abdel Hady, M. (2005) Water movement under saturated and unsaturated flow in coarse textured soils under baharia oasis conditions. Egyptian Journal of Applied Sciences, 20, 358-370.

[25] Ragab, A.A.M., Hellal, F.A. and Abd El-Hady, M. (2008) Water salinity impacts on some soil properties and nutrients uptake by wheat plants in sandy and calcareous soil. Australian Journal of Basic and Applied Sciences, 2, 225- 
233.

[26] Lange, M.L., Webb, B.L., Jolley, V.D. and Nelson, S.D. (2005) Long-term effects of surface applied amendments in reclamation of sodic soils. Western Nutrient Management Conference, Salt Lake City.

[27] Abdelhamid, M.T., Shokr, M.B. and Bekheta, M.A. (2009) Effects of induced salinity on growth, root characteristics and leaf nutrient accumulation of four faba bean (Vicia faba L.) cultivars differing in their broomrape tolerance. Journal of Agricultural Research, 9, 59-67.

[28] Abdelhamid, M.T., Darwish, D.S., Abdalla, M.M.F. and El-Masry, R.R. (2005) Response of faba bean (Vicia faba L.) to orbanch crenata infestation in relation to different watering regimes. Organic Farming: An Option to Reduce Environmental Degradation, Italy.

[29] El-Beltagi, H.S., Salama, Z.A. and El Hariri, D.M. (2008) Some biochemical markers for evaluation of flax cultivar under salt stress conditions. Journal of Natural Fibers, 5 , 316-330. doi: $10.1080 / 15440470802252487$

[30] Azzoz, M.M. (2004) Proteins, sugars and ion leakage as a selection criterion for the salt tolerance of three sorghum cultivars at seedling stage grown under $\mathrm{NaCl}$ and nicotinamide. International Journal of Agriculture and Biology, 6, 27-35.

[31] Khattab, H. (2007) Role of glutathione and polyadenylic acid on the oxidative defense systems of two different cultivars of canola seedlings grown under saline conditions. Australian Journal of Basic and Applied Sciences, 1, 323-334.

[32] Hassann, M.M., El-Masry, T.A. and Abou Arab, A.A. (1999) Effect of soil salinity on growth, yield and elemental concentration in tomato. Egyptian Journal of Horticulture, 26, 187-198. 